\title{
Leading from the Rear? A Theoretical Analysis of the Contingent Bureaucratic Conservatism of the NZCTU Leadership
}

\author{
Brian S. Roper*
}

This article outlines the theory of the contingent bureaucratic conservatism of full-time trade union officials, considers some of the major criticisms of this theory, and then argues that a qualified version of this theory is essential to making sense of the role played by the NZCTU leadership in industrial relations.

\section{Introduction}

The New Zealand Council of Trade Unions was established as a national trade union federation at its inaugural conference in October 1987. It united, for the first time, the overwhelming majority of public and private sector unions (Wilson, 1991). By 1989 public and private sector union membership had risen to 648,825 representing 63 percent of the fulltime workforce (Harbridge et al., 1994: 175-6). Hence both in terms of membership numbers and coverage as well as organisation and resources, the new federation was potentially the most powerful in New Zealand's labour history (Brosnan et al., 1990: 102, 124-25).

While the membership and resources of the NZCTU are considerable, throughout its short history the new federation has had to contend with an extremely difficult and hostile economic, industrial and political environment. During the period from the election of the fourth Labour Government in 1984 until the introduction of the Employment Contracts Act in 1991, the NZCTU faced: high levels of unemployment; the decline of industries in which the traditionally more militant unions were based; a rise in business political activism and the emergence of industrial militancy amongst employers; a shift in the prevailing economic orthodoxy from Keynesianism to neoclassicism and within industrial relations from pluralism to unitarism; and the implementation of a New Right policy agenda by Labour and National governments which is essentially pro-business and anti-worker. ${ }^{1}$

* Lecturer in Political Studies, University of Otago

For accounts of the wider context of industrial relations in New Zealand see: Bollard and Buckle, 1987; Boston and Holland, 1990; Boston and Dalziel, 1992; Easton, 1989; Kelsey, 1995; Roper and Rudd, 1993; Roper, in press a, in press b; Rudd and Roper, in press. 
The National Party, Business Roundtable, Employers Federation, Treasury and new classical economists deny that this policy agenda has mainly benefited a wealthy and powerful minority in New Zealand society. However, the overwhelming bulk of empirical data shows that the only group to have experienced a substantial rise in real disposable household income since 1984 is the top quintile. The majority of workers have experienced either a decline or, at least, no significant rise in real income, deterioration of their conditions of employment, and greater employment insecurity. In fact, it is undeniable that income and wealth has become much more unequally distributed since $1984 .^{2}$

This situation raises some interesting questions because, despite the evident potential power of the NZCTU, and the fact that these policies have been clearly detrimental to the interests of the workers it represents, it consistently failed to successfully oppose and defeat any of the major policy initiatives of the fourth Labour Government or the succeeding National Government. In particular, during the period leading up to the passage of the ECA in May 1991 the NZCTU leadership failed to organise and lead the kind of generalised strike action that would, at the very least, have forced the National Government to substantially amend, if not withdraw, the legislation. In the industrial relations literature there have been remarkably few attempts to address the key questions which this raises: Why has the NZCTU leadership acted in such a conservative and timid manner in response to economic, social and industrial relations policies which have resulted in declining or stagnant real incomes, a deterioration of conditions of employment, and less employment security for the majority of the workforce? And, in particular, why did the NZCTU, despite the breadth and depth of working class opposition to the Employment Contracts Bill, completely fail to force the government to make any significant changes to the legislation?

Sound answers to these questions can be provided through systematic historical research guided and informed by the theory of the contingent bureaucratic conservatism of full-time union officials (also known as the rank and filist perspective). Of course, bureaucratic conservatism is not the only factor which must be considered when investigating the course of particular industrial disputes and therefore it is always important to analyse the wider historical context of a dispute. This includes the general state of the economy, prevailing balance of power between employers and workers, dominant economic orthodoxy, and policy agenda of the government. Hence explanatory accounts of the conservatism of the NZCTU leadership, if they are to be convincing, must combine theoretical analysis of the contingent bureaucratic conservatism of full-time trade union officials in the industrial relations systems of advanced capitalism with systematic historical research which disentangles the concrete interplay of economic, class, ideological and political forces specific to any particular dispute.

The primary objective of this article is to highlight the relevance and potential fruitfulness of the theory of the contingent bureaucratic conservatism of trade union officials for the study of labour history and industrial relations in New Zealand. Specifically, the theory can be used

The growth of income inequality during the 1980 s is widely established (Income Distribution Group, 1990; Department of Statistics, 1993: ch.15, Department of Statistics, Key Statistics, August 1994: $42-43$ and December 1995: 49-50; Economist, November 1994: 20; Kelsey, 1995: 256-59; Roper, in press b). 
to develop a convincing historical explanation of the timidity, conservatism and ineffectiveness of the NZCTU leadership's responses to the attacks of militant employers and anti-working class New Right policies.

Two qualifications need to be made at the outset. First, this article does not develop an original theoretical position. The theory of the contingent bureaucratic conservatism of union officials has a long history within the classical Marxist tradition and more recently has been refined and applied by, among others, Anderson (1967), Bramble (1993), Callinicos (1995), Cliff and Gluckstein (1986), and Richard Hyman $(1971 ; 1975)$ in his early work. In particular, Bramble (1993) provides a highly sophisticated explication of the theory and this article draws heavily on his work. Second, the article relies on the empirical research of Dannin (1995) and Heal (1994). These two studies complement each other in important respects and together provide a reasonably comprehensive historical account of the struggle for and against the ECA.

\section{The contingent bureaucratic conservatism of full-time trade union officials}

Following the identification of the trade union officialdom as a conservative social layer in the Webbs' classic Industrial Democracy, published in 1897, there have been many attempts to explain the evidently conservative industrial and political practice of full-time union officials. These span a wide range of intellectual and ideological perspectives from the revolutionary socialism of the classical Marxists to the liberal pluralism of British and American political science. Max Weber's (1946: 196-240) analysis of bureaucracy and Robert Michels' (1962) study of the "oligarchic tendencies of modern democracy" have been among the major non-Marxist intellectual influences on the debate concerning the conservative propensities of the trade union officialdom.

For Michels the conservatism of union officials reflects their desire to maintain the power and privileges of leadership dominance within their organisations. In Political Parties he argues that oligarchic tendencies characterise all large scale organisations, whether trade unions or political parties, for three sets of reasons. First, there are the "technical and administrative causes" of leadership dominance which arise because of the "mechanical and technical impossibility of direct government by the masses" (1962: Part I). Second, there are "psychological causes of leadership dominance" which arise because there exists a "natural greed for power" amongst leaders and "the desire to dominate ... is universal" (1962: 205-6). In addition the masses are grateful to, and tend to venerate, their leaders. Third, there are "intellectual factors" which underpin leadership dominance. Leaders are generally intellectually superior to the led and consequently the latter are dependent on the former. The dominance of the leadership rests on the "incompetence of the masses"(1962: 107-14).

Not surprisingly in view of the conservative implications that this kind of analysis has for industrial and political practice, Marxists have attempted to provide a more sophisticated analysis of leadership dominance within trade unions which recognises, not only the mechanisms which underpin leadership dominance, but also the mechanisms which can, in 
specific historical conjunctures, undermine it (for useful reviews of the Marxist literature see, Clarke and Clements, 1977; Hyman, 1971; Kelly, 1988).

The most fundamental reason for the conservatism of full-time union officials is the fact that their role in conducting negotiations and making compromises with employers is dependent upon the continued existence of a social and economic system - capitalism - which centrally involves the subordination and exploitation of the workers they represent. ${ }^{3}$ However, while the leadership of trade unions tends to be conservative in the sense of having a commitment to the existing capitalist system and a propensity to oppose militant industrial action, trade unions nonetheless play a vital role in defending workers' interests within capitalism because they ameliorate subordination and exploitation. Richard Hyman observes in this regard that:

\begin{abstract}
Because the economic power of capital - reinforced by a battery of legal sanctions - is so great, the amount of control which can be exercised by employees as individuals is extremely limited. Only when they band together in common action can they begin to make serious inroads into the dominance of the employer (1975: 32).
\end{abstract}

The key point is that while union organisation enables workers to defend their interests within capitalism, their officials do nothing to seriously challenge capitalist social relations. In particular, union officials will do everything in their power to avoid a "head to head" confrontation with employers and the state in the form of a general strike.

As Bramble (1993) makes clear, the theory of the contingent bureaucratic conservatism of union officials rests on a number of core propositions. First, stable collective bargaining in advanced capitalist societies requires the development of a separate and specialised layer of full-time officials within unions who negotiate the terms and conditions of employment of union members. The bargaining functions of union officials are institutionalised and codified by the state in order to maintain the stability of capital-labour relations.

Full-time union officials are divorced from rank and file members by conditions of work and pay, location in a bureaucratic hierarchy, and usually geographic isolation. They develop an interest in maintaining their own relatively privileged position within the industrial relations system. Such officials will defend their own interests when they are threatened by employers, government or by their own members who refuse to recognise their legitimacy and authority. It is naive and unrealistic to assume that the interests of rank and file members, and the interests of the officials who represent them, will necessarily coincide. In fact, union officials will often not hesitate to sacrifice their members' interests in order to maintain their own.

Rank and file control over officials varies tremendously between individual unions, but generally it is weak and the effective accountability of officials to their members is minimal.

The term "exploitation" is used here in the Marxian sense. Workers are exploited because they produce a surplus product over and above that required to meet their basic needs for subsistence which is appropriated by a dominant capitalist class (for an outline of the Marxian theory of surplus value and references see Roper, in press a and in press b). 
It is extremely difficult for union members to remove unpopular high ranking officials even in unions where these officials are formally elected.

The loyalty of union officials to established bargaining relations leads them to support formal procedures associated with arbitration, mediation and collective bargaining and often to condemn industrial action, especially that which is not within their control. Full-time union officials therefore constitute a conservative layer in terms of industrial practice, both in the demands that they are willing to sanction and in the methods that they are prepared to endorse in the pursuit of given demands. Because union officials' primary role within capitalism is collective bargaining, involving negotiation and compromise, they will, unless subject to severe rank and file pressure, seek to avoid generalised strike action. Officials are solidly committed to reformism and during periods in history when the continued existence of capitalism is threatened by the emergence of a revolutionary movement they will do everything in their power to undermine the movement and defend the existing system.

Finally, the bureaucratic conservatism of union officials is historically contingent because as a distinct social stratum, officials are subject to changing economic conditions and contradictory and conflicting sets of social forces. Officials are subject to pressure from below from their rank and file members and from above by frequently hostile employers and by government which generally sides with employers in significant industrial disputes.

Let us consider this in a little more depth. First, as Bramble (1993: 39-40) argues, it is important to recognise that the tendency of full-time officials to pursue a relatively conservative industrial practice is dependent upon the willingness of the members to support continued industrial peace in relations with employers. For the most part rank and file members at least acquiesce in, if not actively support, their officials' industrial practice. However, a shift of mood among rank and file members, either before or during an industrial dispute, may bring these members into conflict with their union leaders and the latter's workplace supporters. Rank and file pressure can force full-time union officials to respond. The specific form that such a response may take is difficult to predict and depends to a considerable extent on the specific circumstances of the dispute. In some circumstances fulltime officials may seek to accommodate the pressure from below in order to preserve the substance of leadership dominance. This may involve taking a more militant stance against employers. On other occasions, they may actively, and sometimes duplicitously, suppress and/or divert rank and file demands for industrial action.

Unions are also subject to pressures from employers and the state, particularly during periods of economic crisis when employers are under pressure from declining profit rates and the state is under fiscal pressure (Roper, in press a). Declining profitability, particularly when labour productivity is not growing, places employers under acute pressure to cut labour costs. When the state is under fiscal pressure it is more likely to adopt a militant stance in negotiations with its employees. In short, the less favourable the economic environment, the more pressure that is placed on union officials by employers and the state to accept sacrifices in members' wages and conditions in order to maintain the underlying viability of the system. Because of their loyalty to the capitalist system, it is likely that officials will acquiesce to employer demands. 
To sum up. Full-time trade union officials constitute a distinctive social stratum, with its own interests, in capitalist societies. Because of the bargaining functions that they perform within the industrial relations system, and because of their conditions of work and isolation from the rank and file, union officials tend towards conservatism in industrial practice, particularly during large scale industrial disputes. It is important to recognise that the tendency towards bureaucratic conservatism within trade unions is precisely a tendency. There have been, and will continue to be, significant exceptions. Furthermore, bureaucratic conservatism is historically contingent since union officials are subject to contradictory, conflicting and changing sets of social, economic and political pressures.

\section{Criticisms of the theory of contingent bureaucratic conservatism}

The theory of the contingent bureaucratic conservatism of full-time trade union officials, commonly referred to as the "rank and filist perspective", has been subject to extensive criticism (Heery and Fosh, 1990; Heery and Kelly, 1990; Hyman, 1989: ch.6; Kelly, 1988: ch.7; Zeitlin, 1987, 1989a, 1989b). The critics have argued that: i) the conservatism of fulltime union officials cannot be explained by reference to the specific nature of officials' working lives nor their involvement in collective bargaining; ii) there is no clear divergence of interests between the trade union officialdom and the rank and file; iii) there is no clear dividing line within the organisational hierarchies of unions between the "officialdom" or "union bureaucracy" and the rank and file; iv) union officials are, contrary to the claims of rank and filists, actually responsive to the wishes of rank and file members; and v) full-time officials do not necessarily tend to conservatism and rank and file members to militancy. In this section of the article these criticisms will themselves be subject to critical scrutiny.

Kelly (1988) argues that the conservatism of full-time union officials cannot be explained by reference to the specific nature of officials' working lives which generally involve higher pay and greater employment security than that experienced by union members, geographic and organisational isolation from rank and file members, and the power and prestige associated with union leadership. In particular, the higher rate of pay that some officials get relative to the workers that they represent cannot be a factor explaining officials' conservatism since high paid workers can be industrially militant and low paid workers quiescent (1988: 161-65).

In response the more sophisticated rank and filists accept that there is no mechanical relationship between high or low wages and high or low rates of industrial militancy amongst sections of the workforce. Rather, they argue that, regardless of whether or not an official earns more than rank and file members, the overall effect of the officials' working conditions is to isolate him or her from those he or she represents (Bramble, 1993: 17-21). As Callinicos observes:

Full-time officials are removed from the discipline of the shop floor, from the dirt and dangers often found there, from the immediate conflicts with the supervisor and manager, from the fellowship of their workmates, to the very different environment of an office. Even if they are not paid more than their members (and they usually are), their earnings no longer depend on the ups and downs of capitalist production .... If a plant is closed the official who negotiates the redundancies will not get the sack. Constantly closeted with management, full- 


\begin{abstract}
timers come to see negotiation, compromise, the reconciliation of capital and labour as the very stuff of trade unionism. Struggle appears as a disruption of the bargaining process, a nuisance and an inconvenience, which may threaten the accumulated funds of the union. The efficient running of the union machine becomes an end in itself, threatening even the limited goal of improving the terms on which the worker is exploited (1995: 17-18).
\end{abstract}

The point is that it is not simply the high salaries of union officials in national leadership positions that predisposes them to conservatism in industrial practice, but rather that this is the overall effect of their working conditions: geographic and organisational isolation, lack of accountability, commitment to established bargaining procedures, and so forth.

Critics of the rank and filist perspective argue that it is empirically unfounded because there is no clear organisational dividing line between the "officialdom" and the rank and file. The internal organisational hierarchies of unions are complex and there is a high degree of variation in organisational structure between individual unions; consequently the division between the officialdom and the rank and file is blurred. Further, the interests of the union officials and of the rank and file are not uniform and both are divided internally as well as against one another (Hyman, 1989: 158; Kelly, 1988:154-155; Zeitlin, 1989a: 49). Rather than there being a clearly defined bureaucracy separate from a coherent and conscious rank and file, intra-union relations are highly complex, with shifting interest groups and bureaucratic tendencies apparent at many levels. In this vein Hyman (1989: 158) has argued that "the problem of 'bureaucracy' denotes not so much a distinct stratum of personnel as a relationship which permeates the whole practice of trade unionism."

In reality it is true that there is no simple and clear cut distinction between the rank and file and the union officialdom. Unions have complex bureaucratic organisational structures which can encompass ordinary rank and file members, unpaid workplace delegates, elected regional executive members, regionally based paid organisers, and full-time national officers. The demarcation problems involved in distinguishing between the union officialdom and the rank and file arise when one moves down the union hierarchy to regional organisers, elected unpaid regional office holders, and workplace delegates. If one must draw a "demarcation line" between the rank and file and the union officialdom, then a key consideration is whether a position is paid or unpaid, and if it is paid then by whom (in Britain some shop stewards are paid by their employer while working full-time on union business). As a general rule all fulltime paid union officials form part of the union bureaucracy, although it is the case that the bureaucracy, like the rank and file, is heterogeneous.

In general, the tendency to bureaucratic conservatism grows stronger as one moves up the union hierarchy (although, obviously, there are some exceptions). For example, regional organisers are likely to be more responsive to rank and file demands than national officers. However, regional organisers are typically bureaucratically appointed and are dependent for their positions on the continued patronage of the national leadership. This article is primarily concerned with the conservatism of the NZCTU leadership, and there can be no doubt that the members of the NZCTU's National Executive, and other full-time paid national office holders who are based in Wellington, are "union bureaucrats" in the classical sense. 
The rank and filists argue that, despite the organisational complexity of some unions, and the existence of other sources of intra-union conflict, there is still a discernible divergence of interests between the working-class membership of trade unions and full-time office based officials (Bramble, 1993: 17). This divergence of interests arises because the driving force of economic activity in capitalist society is, given the competitive war which is waged on both commodity and capital markets, the necessity of firms to remain profitable. Profit in capitalist society is the principal, but not the only, phenomenal form assumed by surplus-value. Surplus-value is the monetary form of the social surplus product specific to a capitalist society. In other words, workers produce a surplus product over and above their own subsistence needs, and the exchange-value of this surplus product is equivalent to surplusvalue. The surplus-value produced by workers in capitalist production is appropriated by capitalists by virtue of their exclusive ownership (in the sense of effective control) of the means of production. Hence the divergence of interests between rank and file union members and union officials arises because "the task of trade unions . . . is to defend workers' interests within capitalist relations of production, within the wages system. The unions exist to improve the terms on which the worker is exploited, not to put an end to exploitation." (Cliff and Gluckstein, 1986: 26)

Agreements reached between unions and employers through collective bargaining within capitalism, even where such agreements involve substantial improvements in wages and conditions, only have a marginal impact on the overall process of surplus-extraction. The interests of union officials are inextricably linked to the continued maintenance of legislation codifying agreements reached through collective negotiation of the buying and selling of labour power, which in turn depends upon the continued subordination and exploitation of workers within the production process. In short, collective agreements may be reached with employers which do reflect, to a limited and partial extent, workers' desire for higher wages and better conditions of employment. But such agreements can never more than partially realise workers' interests because they have fundamental interests (inter alia securing the "full fruits of their labour", distributing this according to need rather than profit, and democratic workplace control) which are essentially anti-capitalist.

Zeitlin argues that the rank and filist perspective is inadequate because there is "pervasive evidence" that full-time officials actually are responsive to the wishes of rank and file members, with the result that it has been possible "to keep internal tensions within tolerable bounds" (1989a: 58-9). This criticism has some force against simplified versions of the rank and filist perspective, but not against those which recognise that the conservatism of officials is contingent because they are subject to contradictory and conflicting social forces, the relative weight of which can change rapidly over time. In unions with a high degree of internal democracy and rank and file participation in union affairs, or during industrial disputes where the rank and file is placing considerable pressure on their officials to act, the officials may be responsive to rank and file demands. But the weight of historical evidence suggests that during large scale industrial disputes union officials tend to adopt a more conservative posture than the rank and file (see for example, Bramble, 1993; Callincos, 1995; Callinicos and Simons, 1985; Cliff and Gluckstein, 1986; Harman, 1988; Moody, 1988; Kerry, 1980; Robertson, 1988). 
The most common, and apparently damning, criticism of the rank and filist perspective, is the claim that full-time officials do not necessarily tend to conservatism and members to militancy. This appears to be a powerful criticism because it is obviously not the case that members are always more militant than officials. Indeed, much of the time it is true that rank and file union members are passive, quiescent and content to support their officials. Ideologically, the majority of the membership may actually be more conservative than the officialdom. It is difficult to articulate a sophisticated response to this, particularly important criticism, in the limited confines of this paper (Bramble provides the definitive response, 1993: 27-33).

Three brief points are particularly worth emphasising. First, workers' structural location within the economic structure of capitalism means that they are subject to periodic attacks by employers on their wages and conditions of employment. Rank and file workers experience these attacks much more immediately than union officials who are shielded from them for the reasons outlined above. Second, related to this:

many unionised workers with experience of industrial action share a common frame of
reference whose elements form a basic class consciousness. These include: the need for
workers to stick together, an antipathy to the boss and those who would break strikes, a
suspicion of the role of police on picket lines, and an understanding that workers can only
protect what they have (or improve on it) by being prepared to fight. Such notions are
especially likely to come to the fore in periods of collective industrial action, when workers
are engaged in what Gramsci called "the practical transformation of the real world" (Bramble,
1993: 30).

Third, during large scale industrial disputes workers' consciousness changes very rapidly over short periods of time. Bramble argues in this regard that:

\begin{abstract}
industrial action by trade unionists has a powerful effect in stimulating workers' consciousness of the identity and power of their class. The struggle of rank and file union members has a tendency to break from the legal channels sanctioned by full-time officials, not least because members have no material attachment to the formal procedures of industrial relations. Thus, once mobilised and once conscious of the issues at stake, rank and file members can be rapidly driven into industrial action extending well beyond what their full-time officials are willing to sanction. Sharp swings of membership sentiment can occur with great rapidity, from docility and acquiescence to aggression and confidence and back again, and it is in the fluidity of members' consciousness that they stand in contrast to full-time officials (1993: 31 - my emphasis).
\end{abstract}

As this makes clear, much criticism of the rank and file perspective is misdirected. This perspective recognises that in most unions, most of the time, the rank and file members may be passive, quiescent and ideologically more conservative than their officials. However, during large scale strikes, and a fortiori during periods of generalised strike action, union officials' commitment to the formal procedures of collective bargaining involving negotiation and compromise with employers, leads them to seek to avert "head to head" confrontation with employers and the state. In large scale collective action even ideologically conservative workers can become radicalised in a very short period of time and support militant forms of industrial action being actively discouraged by ostensibly "left wing" officials. 
Finally, the rank and filist perspective has been criticised for focusing excessively on internal conflict within unions and failing to place sufficient weight on the frequently hostile external social, economic and political context in which unions have to operate. Once again this criticism is wide of the mark. Rank and filists readily acknowledge that when considering any specific dispute, particularly where the union has lost, it is important not to focus exclusively on the role of the union officials. It is necessary to place the dispute within a wider societal and historical context (see for example, Roper, 1990).

\section{Relevance of the theory? Explaining the timidity and conservatism of the NZCTU leadership}

As mentioned earlier, from the outset the NZCTU faced the hostility of employers who had been growing increasingly industrially militant and politically active throughout the $1980 \mathrm{~s}$ and Labour and National governments intent on ramming through a comprehensive programme of New Right economic, social and industrial relations policy reform which was clearly detrimental to the interests of workers (Roper, 1993: 160-62; Walsh, 1993: 184-89). In response to these attacks, the NZCTU leadership continually emphasised the need for negotiation and compromise with both employers and government, while demonstrating a complete disdain for industrial action and political protest. It is the central contention of this article that the theory of the contingent bureaucratic conservatism of the union officialdom both explains, and is empirically corroborated by, the largely timid, passive, conciliatory, and conservative response of the NZCTU leadership to the succession of attacks on its members by the fourth Labour Government and following National Government. While it is not possible to provide a detailed empirically grounded account of the performance of the NZCTU leadership from 1987 to the present, it is possible to make a number of general observations.

First, the theory of bureaucratic conservatism emphasises that the union bureaucracy is a distinct social stratum with its own interests which is, particularly in the upper echelons of the union federation, subject to minimal rank and file control over its activities. This is clearly the case with the NZCTU leadership. Even in terms of its formal structure the democratic accountability of the NZCTU leadership to its rank and file members is minimal. Unlike the FOL which held annual conferences, the NZCTU only holds conferences on a biennial basis. The President, Vice President and Secretary/Treasurer are only subject to election once every four years (less frequently than the Prime Minister!), there is no effective constitutional mechanism enabling rank and file members of affiliated unions to remove the President or Vice President from office for inadequate performance, there is no constitutional requirement for union officials to vote in accord with the wishes of the majority of their members in special meetings of affiliates, nor is there any constitutional requirement that affiliated unions be internally democratic (NZCTU, 1994: 49-73). In short, effective democracy is virtually non-existent within the NZCTU's organizational structure.

The full significance of the lack of democracy within the NZCTU becomes clear when it is recognised that the majority of rank and file members failed to support the leadership's two major "strategic responses" to attacks by Labour and National governments between 1987 and 1991. In response to the economic restructuring and public sector reform of the fourth 
Labour Government it advocated "strategic unionism" and a Compact modelled on the Accord between the Australian Council of Trade Unions and the Hawke-Keating federal governments (Harvey, 1992). When this failed in the wake of the defeat of Labour in the 1990 general election, it responded to the National Government's introduction of the Employment Contracts Bill by "leading from the rear", that is refusing to provide national co-ordination for industrial action and political protests against the proposed legislation (Campbell, 1991). As the historical accounts by Dannin (1995) and Heal (1994) have shown, the "strategic unionism" developed in response to the fourth Labour Government contributed to the NZCTU's complete failure to provide national co-ordination and leadership for the struggle against the Employment Contracts Act.

The strategic unionism adopted by the NZCTU during the late 1980s rested on a trade-off in which it agreed to exercise real wage restraint in exchange for greater union involvement in the formation of economic, social and industrial relations policy by government. As Bramble and Heal observe the central idea was that:

unions had to move away from arguing over the distribution of the proceeds of production to intervening in the process of production itself and, at the national level, in economic policy processes which were the ultimate determinant of employment opportunities for union members. This required that unions took responsibility for increasing productivity and cutting wage costs (in press).

Strategic unionism was promoted as a "third way" between the heavy handed intervention of "Muldoonism" and the hard line monetarism of "Rogernomics". The key problem for the NZCTU in trying to persuade the Labour Government to adopt the strategy was that its "lack of control over individual unions and its keenness to quell union militancy meant that government and employers could justifiably discount the threat of union opposition to reform, thus negating the need for a genuinely corporatist framework (Bray and Neilson, 1996: 79)." In an historical conjuncture characterized by the highest level of unemployment since the 1930 s and a decisive shift of the "balance of class forces" in favour of capital, both employers and government realised that they did not require the co-operation of union officials to push through cuts to wages and conditions, nor in order to introduce legislation establishing a more decentralised bargaining structure. Finally, it is important to recognise that strategic unionism is entirely explicable in terms of contingent bureaucratic conservatism: at its core is an emphasis on negotiation and compromise with, rather than struggle against, employers and the government.

In order to implement this strategy the NZCTU negotiated a Compact with the Labour Government in late 1988 but this "was little more than an agreement to discuss industrial relations and seemed to lead to nowhere (Bray and Neilson, 1996: 79)." Finally, in an act of desperation the NZCTU signed a Growth Agreement with the government six weeks prior to the 1990 election. It limited nominal wage rises to two percent, unless justified by higher productivity, in the context of five percent inflation, in return for a Reserve Bank commitment to cut interest rates and a vague promise from the government to consult the NZCTU about economic, industrial relations and social policy (Walsh, 1992: 62). 
The response of the NZCTU to the election of National in the 1990 election and the new governments' rapid introduction of the Employment Contracts Bill, was profoundly shaped by the discouragement of industrial action and political protest that lies at the core of strategic unionism. In this regard, Bray and Neilson observe that "there seemed little room to maintain a more traditional action-oriented militant politics, since that would undermine the union movement's credibility as a mature economic partner at a national level (1996: 78)." This meant that in response to the State Sector Act of 1988 and the associated drive of the Labour Government for mass redundancies amongst public sector workers, "The NZCTU was keen to show that it could resolve disputes rather escalate them and it discouraged open resistance (1996: 77)." The abject failure of the NZCTU to defend the interests of its members in opposition to the anti-working class policies of the fourth Labour Government was highly significant because as Dannin (1995) and Bramble and Heal (in press) have shown:

\begin{abstract}
The CTU's formal and institutional alliance with Labour left it unable to criticise Labour when it privatised government agencies and deregulated industries. In turn, by failing to keep faith with its membership and by failing to promote their interests within their party, the CTU became estranged from its membership and allies and thus weakened. A large number of the public looked to the CTU for leadership and heard nothing (Dannin, 1995: 39).
\end{abstract}

Even after the election of a National Government clearly committed to sweeping attacks on the trade union movement, the NZCTU response was to seek negotiation and compromise. According to Robyn Haultain, a former CTU counsel:

\begin{abstract}
There was a lot of internal discussion [within the NZCTU] about whether we should start meeting with Bill Birch, from the National Party, and with people who we knew were going to be at the forefront of the charge as far as voluntary unionism and so on was concerned.

All of the people who worked in the technical services division had a very strong opinion that we ought to be meeting with Birch and as many other National Party people as we could (interview cited by Dannin, 1995: 40).
\end{abstract}

While these meetings did not eventuate, the fact that they were seriously considered at this crucial juncture highlights the "negotiate and compromise" ethos of the NZCTU.

From the outset it was widely recognised that the central provisions of the Employment Contracts Bill would fundamentally undermine union membership and coverage, organisation, collective action and bargaining power. ${ }^{4}$ The bill was introduced in conjunction with significant reductions in benefit rates and the introduction of much harsher eligibility criteria (Boston and Dalziel, 1992). In particular, a six month stand down period was introduced for the unemployment benefit for workers who left their jobs "without a good and sufficient reason" or lost their job through "misconduct" (Stephens, 1992: 109). Workers taking strike action were also ruled to be ineligible for the unemployment benefit. Early in 1991 the popularity of National, as reflected in opinion polls, declined to an historic low for a governing party. The implementation of the New Right policy agenda from 1984 onwards, with the resulting substantial upward redistribution of income and the "down sizing" of the

4 In the event, total union membership declined from 603,118 in May 1991 to 362,200 in December 1995, with a decline in union density (full-time equivalent union members to the total workforce) from 41.5 percent to 21.7 percent (Crawford, et al., 1996: 188; Harbridge, 1993). 
welfare state and public service, generated widespread anger amongst the working class. But this anger remained latent because of the extensive demoralisation of rank and file union members due to high unemployment, the increasingly defensive and unsuccessful nature of strike action during the 1980 s, and the failure of the NZCTU to lead a fightback against the Labour Government's attacks on workers. The combination of the benefit cuts and the attack on the union movement legislatively embodied in the ECB provided a focus for this anger. Hence during the early months of 1991 there was a remarkable, and largely spontaneous, growth of working class opposition to the legislation.

The overwhelming weight of the available evidence suggests that during March and April of 1991 a clear majority of rank and file union members came to support generalised strike action in order to force the government to amend or withdraw the bill. This is clear from the scale of the protests against the bill - the largest since the 1981 Springbok Tour, the size and mood of mass stopwork meetings, opinion polls which highlighted the unpopularity of the ECB (National Business Review, 1991, May 15: 4), and the results of union ballots endorsing nation-wide strike action (Heal, 1994: ch.5). The precise level of support for a general strike during April can not be accurately determined because, unfortunately, no reliable national survey of rank and file union members' attitude towards the proposal for a general strike was conducted. However, there is not a single documented instance amongst the major unions of workers failing to endorse, and by very large majorities, strike action where they were balloted.

Workers felt much more confident about participating in a general strike against the ECB than in isolated strikes within their own unions (Heal, 1994: ch.5). As Bramble and Heal (in press) observe:

\begin{abstract}
At the time of its enactment, the bill was widely opposed and the National Government itself was extremely unpopular after only six months in office. The key task for the CTU was that of mobilising opposition to the bill in a public and politically-damaging fashion to the government. Central to this was the organisation of a general strike amongst all unionists. Such action was a step that could have forced the government to back down and, perhaps paradoxically, the only form that would attract solid support from the largest number of workers. That a general strike would have hurt National's business backers is evident. But economic uncertainty and an aggressive employer mentality meant that any strategy based on partial actions, involving only small groups of workers, was bound to fail as workers stayed at work fearing victimisation.
\end{abstract}

While the NZCTU did succeed in producing and disseminating useful information which highlighted the disastrous impact that the ECB was going to have on union organisation, it completely failed to engage in this key task. As Dannin shows in her meticulously detailed account of the struggle against the ECB:

Throughout its pendency, everyone wondered when and if the CTU would call for a general strike. If the CTU can be faulted for anything, it is in this area. From the introduction of the ECB to its enactment, the CTU vacillated and finally did nothing. The CTU failed to provide a cohesive public, visible leadership in opposition to the ECB and, instead, left others to take the lead or to flounder because of its lack of direction (1995: 74). 
The formally stated position of the NZCTU leadership was essentially that it was up to individual unions to decide what action, if any, they would take in opposition to the ECB. In reality, however, key figures in the leadership, particularly President Ken Douglas, VicePresident Angela Foulkes and officials from the Engineers Union, did seek to exert influence over the struggle against the ECB. That influence was directed against those rank and file militants, unions and officials who were pushing for a general strike (Bramble and Heal, in press; Dannin, 1995: 84-85).

On the 18th of April 1991 a Special Affiliates Conference was held to determine the course of action that would be adopted by unions affiliated to the NZCTU in opposition to the ECB. Immediately prior to the conference the NZCTU leadership signalled its opposition to a general strike and it did not present the conference with a proposal for nationally coordinated strike action. In the conference itself the national office holders in major unions block voted 250,122 to 190,910 against the Service Workers Federation's proposal for a 24 hour nationwide strike (New Zealand Journal of Industrial Relations, 16: 203). This decision had an immediate demoralising effect because rank and file union members were well aware that nothing less than a general strike would force the government to withdraw or amend the legislation. This conference decision effectively meant that the union movement had missed an historic opportunity to at least slow down the continued implementation of the New Right policy agenda. It also constituted a travesty of the most elementary principles of democracy. Officials block voted against the proposal for a general strike despite the fact that they had no mandate from their rank and file members to do so. Indeed, the majority of rank and file members in these unions would have endorsed and supported such action.

The arguments that have been made in defence of the role played by the NZCTU in the struggle against the ECA are not convincing. First, leading figures in the NZCTU claim that there was insufficient rank and file support for a general strike, meaning that if a general strike had been called it would have been unsuccessful and merely highlighted the weakness of the unions. While it must be acknowledged that there is insufficient evidence to conclusively prove that a majority of rank and file union members supported a general strike, there is far less, if any, evidence to suggest that a majority actually opposed strike action. Second, Easton (1995) among others, argues that a general strike would not have forced the government to withdraw or amend the legislation. It is true that a 24 hour general strike on its own would not have been sufficient to force the government to amend the legislation. But a successful general strike would have raised workers' confidence and could have been followed by further generalised strike action and mass protests. Indeed, given the breadth and depth of popular opposition to the government at the time, and the likelihood of genuinely mass support for the initial general strike, it is possible that key sections of the workforce may have decided to stay out longer than 24 hours without direction from their officials. In the face of such opposition it is likely that the government would have, at the very least, modified the legislation in order to defuse the situation (it was subsequently forced into u-turns on some of its initiatives in superannuation and health). 


\section{Conclusion}

The argument in this article raises an apparent anomaly: if the distinctive interests of the union officialdom rest in the maintenance of their role in collective bargaining, and the ECB undermined collective bargaining, then why didn't NZCTU leadership oppose the ECB more forcefully? The major reason is that the positions, power and salaries of the members of the NZCTU National Executive were in no way directly threatened by the ECB. The union officialdom is not homogeneous and there is a differentiation of interests within it. In essence, by failing to coordinate a nation-wide campaign of generalised strike action in opposition to the legislation, the NZCTU leadership was sacrificing the interests, not only of the rank and file, but also sections of the union officialdom.

It is simplistic and false to assert that "officials always sell out" their rank and file members. Non-Marxist scholars frequently have great difficulty in grasping the subtleties of sophisticated contemporary classical Marxist analysis. It would involve a gross misrepresentation of the theory of contingent bureaucratic conservatism to suggest that this theory rests on a simplistic assumption of continual militancy amongst the rank and file and conservatism amongst the union officialdom. One of the major strengths of the theory is precisely its capacity to identify not only the mechanisms which underpin leadership conservatism and dominance within trade unions, but also the mechanisms which can, in specific historical conjunctures, undermine it. By recognising that the bureaucratic conservatism of union officials is contingent, the theory provides an analytical framework of considerable sophistication and explanatory power which can be used to guide historical and empirical research in the related fields of industrial relations and labour history.

This author considers that the struggle against the ECA in 1991 should rank alongside the 1890 Maritime Strike, 1913 Waterfront Strike, and the 1951 Waterfront Lockout as one of the most significant in New Zealand's labour history. Up to this point, Dannin (1995) and Heal (1994) provide the most detailed historical accounts of the struggle for and against the ECA. While this work makes an invaluable contribution, there remain many avenues open for further research into the "making of the ECA". There is an urgent need for a more detailed general historical account of the struggle for and against the ECA than Dannin could provide in a lengthy article and Heal was able to provide within the limited confines of an MA thesis.

There is no detailed historical account of the way in which the class consciousness of rank and file union members developed and changed during the course of the struggle against the ECB. There is anecdotal evidence that the consciousness of rank and file union members was highly fluid and changed week by week; becoming more confident and militant as the campaign against the ECB gathered momentum in March and April before plunging into despair and demoralisation after the decision of the Special Affiliates meeting on the 18th of April was announced. But there is no systematic empirical evidence to support this view.

Regional case studies, particularly a study focusing on Auckland, would provide a valuable supplement to, and would enable critical scrutiny of the reliability of, the more general accounts of the struggle for and against the ECA. Alternatively it would be useful to obtain 
accounts of the struggle focusing on the roles played by particular unions, focusing not just on the officials in these unions but also the rank and file. Adopting this kind of detailed case study approach might make it possible, if supplemented by in depth interviews with rank and file union members, to trace the way in which rank and file sentiment changed during the early months of 1991 .

Dannin and Heal's research could also be usefully supplemented by a more detailed account of the changing position of the NZCTU leadership and "inside" accounts of the responses of employers (NZBR and NZEF) and the National Cabinet to the spontaneous upsurge of working class anger early in 1991 . More generally further research is required in both labour history and industrial relations which adopts a rank and filist perspective.

\section{References}

Anderson, P. (1967), The Limits and Possibilities of Trade Union Action. In Blackburn, R. and Cockburn, A. (eds), The Incompatibles: Trade Union Militancy and the Consensus, Harmondsworth, Penguin.

Bollard, A. and Buckle, R. (eds) (1987), Economic Liberalisation in New Zealand, New Zealand, Allen and Unwin and PNP.

Boston, J. (1984), Incomes Policy in New Zealand: 1968-1984, Wellington, Victoria University Press.

Boston, J. and Dalziel, P. (eds) (1992), The Decent Society? Essays in Response to National's Economic and Social Policies, Auckland, Oxford University Press.

Boston, J. and Holland, M. (eds) (1990), The Fourth Labour Government 2nd Ed. Auckland, Oxford University Press.

Bramble, T. (1993), The Contingent Conservatism of Full-Time Trade Union Officials, Ph.D. thesis, La Trobe University, Melbourne.

Bramble, T. and Heal, S. (in press), Trade Unions. In Rudd, C. and Roper, B. (eds), New Zealand's Political Economy, Auckland, Oxford University Press.

Bray, M. and Neilson, D. (1996), Industrial Relations Reform and the Relative Autonomy of the State. In Castles, F., Gerritsen, R. and Vowles, J. (eds), The Great Experiment: Labour Parties and Public Policy Transformation in Australia and New Zealand, Sydney, Allen and Unwin.

Brosnan, P., Smith, D. and Walsh, P. (1990), The Dynamics of New Zealand Industrial Relations, Auckland, John Wiley and Sons.

Callinicos, A. (1995), Socialists in the Trade Unions, London, Bookmarks. 
Callinicos, A. and Simons, M. (1985), The Great Strike: the Miners' Strike of 1984-85 and its Lessons, London, Bookmarks.

Campbell, G. (1991), Leading from the Rear, Listener, June 3-9: 30-33.

Clarke, T. and Clements, L. (eds) (1977), Trade Unions under Capitalism, Glasgow, Harvester Press.

Cliff, T. and Gluckstein, D. (1986), Marxism and Trade Union Struggle: the General Strike of 1926, London, Bookmarks.

Crawford, A., Harbridge, R. and Hince, K. (1996), Unions and Union Membership in New Zealand: Annual Review for 1995, New Zealand Journal of Industrial Relations, 21(2): 18893.

Cronin, J. (1989), The "Rank and File" and the Social History of the Working Class, International Review of Social History, XXXIV: 78-88.

Dannin, E. (1995), We Can't Overcome? A Case Study of Freedom of Contract and Labour Law Reform. Berkeley Journal of Employment and Labour Law, 16(1): 1-168.

Department of Statistics (1993), New Zealand Social Trends: Work, Wellington.

Easton, B. (1995), The Maturation of the Union Movement. Revised paper to the 1995 Seminar Series of the Department of Political Studies, University of Auckland, August.

Easton, B. (ed.) (1989), The Making of Rogernomics, Auckland, University of Auckland Press.

Harbridge, R. (ed.) (1993), Employment Contracts: New Zealand Experiences, Wellington, Victoria University Press.

Harbridge, R., Hince, K. and Honeybone, A. (1994), Unions and Union Membership: Annual Review for 1993, New Zealand Journal of Industrial Relations, 19(2): 175-180.

Harman, C. (1988), The Fire Last Time: 1968 and After, London, Bookmarks.

Harvey, O. (1992), The Unions and the Government: the Rise and Fall of the Compact. In Deeks, J. and Perry, N. (eds), Controlling Interests: Business, Society and the State Auckland, Auckland University Press.

Heal, S. (1994), The Struggle For and Against the Employment Contracts Act, MA thesis, Political Studies, University of Otago, Dunedin.

Heery, E. and Fosh, P. (1990), Introduction: Whose Union? Power and Bureaucracy in the Labour Movement. In Fosh, P. and Henry, E. (eds), Trade Unions and their Members: Studies in Union Democracy and Organization, Basingstoke, Macmillan. 
Heery, E. and Kelly, J. (1990), Full-Time Officers and Shop Steward Network: Patterns of Co-operation and Interdependence. In Fosh, P. and Henry, E. (eds), Trade Unions and their Members: Studies in Union Democracy and Organization, Basingstoke, Macmillan.

Hyman, R. (1971), Marxism and the Sociology of Trade Unionism, London, Pluto Press.

Hyman, R. (1975), Industrial Relations: a Marxist Introduction, London, Macmillan.

Hyman, R. (1989), The Political Economy of Industrial Relations, London, Macmillan.

Hyman, R. and Fryer, R. (1975), Trade Unions: Sociology and Political Economy. In Clarke, T. and Clements, L. (eds) (1977), Trade Unions under Capitalism, Glasgow, Fontana.

Income Distribution Group (1990), Who Gets What? The Distribution of Income and Wealth in New Zealand, Wellington, New Zealand Planning Council.

Kelly, J. (1988), Trade Unions and Socialist Politics, London, Verso.

Kelsey, J. (1995), The New Zealand Experiment, Auckland, Auckland University Press and Bridget Williams Books.

Kerry, T. (1980), Workers, Bosses, and Bureaucrats, New York, Pathfinder.

Michels, R. (1962), Political Parties, New York, Free Press.

Moody, K. (1988), An Injury to All: the Decline of American Unionism, London, Verso Books.

NZCTU. (1994), 1994 NZCTU Directory, PO Box 6645, Wellington.

Price, R. (1989), "What's in a Name?" Workplace History and "Rank and Filism", International Review of Social History, XXXIV: 62-77.

Robertson, J. (1988), Socialists and the Unions. In International Socialism 41: 97-113

Roper, B. (1990), Contested Terrain, New Zealand Monthly Review 325: 6-13.

Roper, B. (1993), A Level Playing Field? Business Political Activism and State Policy Formation. In Roper, B. and Rudd, C. (eds), State and Economy in New Zealand, Auckland, Oxford University Press.

Roper, B. (in press a), New Zealand's Post-War Economic History: Monetarist, Keynesian and Marxist Views. In Rudd, C. and Roper, B. (eds), New Zealand's Political Economy, Auckland, Oxford University Press. 
10rk: Patterns o Unions and thei cmillan.

, Pluto Press

lacmillan.

Macmillan.

my. In Clarke.

v, Fontana

Ime and Wealth

rsity Press and

Condon, Verso

and Filism"

1: 97-113

Roper, B. (in press b), The Changing Class Structure. In Rudd, C. and Roper, B. (eds), New Zealand's Political Economy, Auckland, Oxford University Press.

Roper, B. and Rudd, C. (eds) (1993), State and Economy in New Zealand, Auckland, Oxford University Press.

Rudd, C. and Roper, B. (eds) (in press), New Zealand's Political Economy, Auckland, Oxford University Press.

Stephens, R. (1992), Budgeting with the Benefits Cuts. In Boston, J. and Dalziel, P. (eds), The Decent Society? Essays in Response to National's Economic and Social Policies, Auckland, Oxford University Press.

Walsh, P. (1992), The Employment Contracts Act. In Boston, J. and Dalziel, P. (eds), The Decent Society? Essays in Response to National's Economic and Social Policies, Auckland, Oxford University Press.

Walsh, P. (1993), The State and Industrial Relations in New Zealand. In Roper, B. and Rudd, C. (eds), State and Economy in New Zealand, Auckland, Oxford University Press.

Weber, M. (1946), From Max Weber: Essays in Sociology, New York, Oxford University Press.

Wilson, A. (1991), The New Zealand Council of Trade Unions: History, Structure and Role, BA Hons dissertation, Political Studies, University of Otago, Dunedin.

Zeitlin, J. (1987), From Labour History to the History of Industrial Relations. Economic History Review, XL(2): 159-84.

Zeitlin, J. (1989a), "Rank and Filism" and Labour History: a Critique, International Review of Social History, XXXIV: $42-61$.

Zeitlin, J. (1989b), "Rank and Filism" and Labour History: a Rejoinder to Price and Cronin. International Review of Social History, XXXIV: 89-102. 